\title{
Robin Hyde and the Long Shadows in the Ladies' Gallery
}

\author{
NIKKI HESSELL
}

\begin{abstract}
Robin Hyde reported from the Ladies' Gallery of the New Zealand Parliament sporadically over seven years. Her reports have been considered in past scholarship but have not been previously located within the tradition of New Zealand women's gallery journalism. This essay argues that Hyde's reports demonstrate strong stylistic and journalistic connections to this tradition, and that these connections in turn inform some of the negative responses her work received from the cultural nationalist writers of the 1930s.
\end{abstract}

In her unpublished novel The Unbelievers, Robin Hyde makes effective use of her time as a parliamentary correspondent in the 1920s and early 1930s. Her protagonists, Echo and Jarah, decide to attend a debate in the House, with Jarah disguising himself as a woman in order to enter the Ladies' Gallery. Echo attempts to follow the debate about wages but finds that it was so full of interpolations and pointless argument, of sarcastic reference from one gentleman as to what another gentleman was recorded as having said ten years before, of the crackling of newspapers and of the deep bass snores of a Maori member, who lay full length on one of the Treasury benches with his boots off, (for which Echo could not bring herself to blame him,) that she could not keep her mind on the game. ${ }^{1}$ Eventually Echo goes into a kind of trance, in which snatches of Robert Louis Stevenson's poetry blend in with the phrases of the debate: 'Equality of sacrifice ... time of crisis ... over-production ... inflated standards of living ... consider themselves fortunate ... Fifty spears they cast ... fifty spears they cast ... [Hyde's ellipsis]'. 'Jarah then shouts accusations at the MPs below and orderlies throw the pair out. They disappear into the Wellington night, while the three lights that indicate that Parliament is in session 'still twinkled, harder than ever'. ${ }^{3}$ This vignette encompasses many of the features of Hyde's early style as a parliamentary reporter: an identity that moves between genders, a sense of bewilderment at the procedures of parliamentary debate, a mixture of the factual and the fictional, connections between literature and Parliament, a fascination with the clichés and stock phrase of the debates, and an awareness of the differences between parliamentary insiders and outsiders.

This essay argues that as well as demonstrating some clear links with Hyde's style in her prose fiction, her parliamentary journalism was shaped and influenced by the legacy of women reporters who had worked in the New Zealand House of Representatives since the late-nineteenth-century, a legacy which included an awareness of their own precarious position in the hierarchy of the press, an interest in parliamentary language, and an attraction to journalistic pseudonyms and persona. While reading Hyde's gallery journalism alongside her literary output is fruitful, this essay proposes that it can also be situated productively in a history of women's reportage, which can in turn provide insights into why Hyde's literary style might have developed as it did, shaped in part by formative experiences reporting from the House. Finally, the essay proposes that the style and the ultimate fate of Hyde's parliamentary journalism can add new texture to debates about the antagonism between Georgianism and cultural nationalism in 1930s New Zealand literature.

\section{Robin Hyde's Career in the Gallery}

Hyde began working as a reporter for the Dominion in Parliament's Ladies' Gallery in 1925, writing a column called 'Peeps at Parliament' under the pseudonym 'Novitia,' which ultimately comprised over 50 articles. $^{4}$ She had been hired by the paper's editor, Charles Earle, to provide 'daily skits about members and Parliament in general'. 5 She quickly 
established a presence at the House, befriending MPs and attracting the attention of the Prime Minister, Gordon Coates. ${ }^{6}$ After working throughout the 1925 session, which culminated in a general election, Hyde resigned from the Dominion in April 1926 when she found she was pregnant. It is clear is that she enjoyed the work. She was very disappointed when an opportunity to act as a parliamentary reporter for the Christchurch Sun fell through in 1928, but decided to take a press pass to the Ladies' Gallery in any case, in the hope of interesting another periodical in taking her on. ${ }^{7}$ Eventually she persuaded the Ladies' Mirror, a monthly magazine for which she was already writing a column about life in Wellington, to accept a second column called 'From the Gallery'. ${ }^{8}$ This column appeared just three times, between August and October 1928. Hyde's only other known piece of parliamentary writing is a 'pen picture' composed for the New Zealand Observer during a visit to her family in Wellington in 1932.

Hyde's journalism was returned to public attention in 1991, when Gillian Boddy and Jacqueline Matthews published Disputed Ground: Robin Hyde, Journalist, a collection of excerpts of her work combined with two introductory essays. Boddy and Matthews established an influential image of Hyde's approach to reporting, remarking that '[h]ers was an uneasy position, the girl child claiming a voice in the man's world of journalism where her precocity and her femininity were at the same time valued and despised'. ${ }^{9}$ Her first foray into parliamentary reporting for the Dominion is described as reflecting 'the newspaper's view of what women wanted to read' in a 'girlish and guileless style' that was 'considered appropriate for women writers'. ${ }^{10}$ The image of Hyde portrayed in Disputed Ground is of someone outside the mainstream, forced into a style of journalism that may not have appealed to her.

A slightly different aspect of Hyde's style is emphasized by her biographers Derek Challis and Gloria Rawlinson in The Book of Iris (2002). Challis and Rawlinson propose that Hyde was being asked to do something new by Earle in 'bringing a little humour and some life into the dull and tedious routine of reporting parliamentary business'. ${ }^{11}$ In response to this request, she adopted 'an unusual style of journalism which sometimes irritatingly blended fact and imagination', and led to the occasional 'disconcerting digression into poetic prose'. ${ }^{12}$ The unconventionality of her style, filtered through her status as a young woman, remains a key feature, however. In Challis and Rawlinson's account, the MPs who read her columns were 'intrigued, amused, irritated or touched by this slip of a girl who watched them from the women's press gallery and then commented on their speeches in the morning press. No doubt they were sometimes disconcerted by the cheekiness of Novitia's comments and preferred the more serious tone adopted by the Dominion's professional parliamentary reporter on the left side of the page'. ${ }^{13}$

Yet Hyde's parliamentary reporting seems to be indeterminate enough to support multiple readings. Even in her own era there was dispute; the MP John A. Lee, a good friend of Hyde's, called her reports 'awful tripe', but a complimentary review written a year before her death noted that she 'became a first class Parliamentary reporter'. ${ }^{14}$ Critics involved in the first wave of resurgent interest in Hyde's work in the 1980s and 1990s have said similarly contradictory things: was her salary as a parliamentary reporter 'huge' for the time, or was she instead employed in a 'lowly, badly-paid job'? ${ }^{15}$ Was she a 'tough-minded parliamentary reporter' or the 'girl child' of Boddy and Matthews' account? ${ }^{16}$ Are readers likely to agree with Annabel Cooper, who concluded that the 'Novitia' pieces were among the 'good bits' of Disputed Ground, or with Margaret Quigley, who suggested that the section of that book in which these pieces appeared 'is probably the most dated and trivial of her writing'? ${ }^{17}$ This article does not attempt to answer these questions directly, but to suggest that one reason for the many contradictory impressions of Hyde's work in the gallery is a lack of understanding about the work of women reporters (both its style and the conditions under which it was 
produced) in the era leading up to and including Hyde's time as a parliamentary reporter, and to outline how these influences, both historical and contemporary, might have shaped her work. The focus of the essay is not on the content of her journalism, although this deserves further scholarship, but on the style she adopted when she produced it.

The contradictions in existing interpretations partly arise from the tendency to read Hyde's parliamentary journalism through the lens of the later literary author, whose outsider status and attacks on the artistic and political establishment of New Zealand, such as her responses to the Caxton group around Denis Glover and her strident articles about the Labour government's handling of the situation at Orakei, make her a compelling and significant figure in the development of the local canon. ${ }^{18}$ But the reasons for attributing this same unconventional style to her parliamentary reports are less certain. No one to date has compared Hyde's reporting with the norms of 1925, nor with the history of women's parliamentary journalism in New Zealand before she came to the House. It is hard to be sure that she was unconventional if it is not clear what were the conventions. I include my own work in this criticism; my past research on Hyde's reporting reflects this lack of engagement, and this article thus revisits my conclusions on her parliamentary journalism but offers some entirely different reflections on its significance for studies both of Hyde and of the context of 1930s New Zealand literature. ${ }^{19}$

\section{The New Zealand Parliament and the Lady Reporter}

Parliamentary reporting in New Zealand had a long pedigree by the time Hyde began work for the Dominion in 1925. After an unsatisfactory period in the 1850s and 1860s, when newspapers or entrepreneurial MPs were the only source of parliamentary speeches, the New Zealand government moved to establish an official record. In 1867, the first authorized staff of parliamentary reporters independent from the newspapers was assembled to create a publication that colloquially adopted the name Hansard from the British example. New Zealand was thus one of the first democracies to produce an official record of its parliamentary deliberations; the British Hansard, which operated as a business independent from the Parliament, did not become the official record until $1909 .{ }^{20}$ The establishment of Hansard meant that the New Zealand newspapers were no longer expected to produce, and no longer had a monopoly on, comprehensive coverage of the House of Representatives. There was now both the freedom and the imperative to be more creative and innovative in the production of parliamentary journalism. The opening of new government buildings in 1873 in Wellington saw the creation of a permanent press gallery, and throughout the 1870s its members consolidated their role as an independent witness to parliamentary proceedings. ${ }^{21}$

One of the most important innovations in New Zealand parliamentary journalism to emerge in the late-nineteenth-century was the use of women reporters, partly in response to the enfranchisement of women in 1893. While there is no complete record of which journalists reported from Parliament, let alone how many of them were women, there are four prominent examples, all of whose work is relevant to Hyde's experience. Laura Suisted was almost certainly the country's first female parliamentary correspondent. ${ }^{22}$ Her freelance reports on the House began appearing in the weekly Otago Witness in June 1884. Her column, which appeared on and off until 1891, went through several incarnations. It began life as 'Jottings from the Seat of Government' by 'The Scribbler'. After a hiatus in 1885, the column returned, in 1886-87 as 'Notes from the Seat of Government' by 'Pearl Pen'.

A second important example is 'Birds' Eye', the reporter for the New Zealand Graphic and Ladies' Journal. The real identity of Birds' Eye is uncertain, but she began a column called 'Our Legislators' in 1893. The column, which was often accompanied by cartoons and other illustrations, ran for only one session, but it was in the crucial year of the 
enfranchisement of women. Birds' Eye's column provided coverage of these fascinating debates for the readers of the Graphic from a woman's perspective.

Perhaps the most famous early woman parliamentary correspondent in New Zealand was Forrest Ross. Ross provided freelance reports for the Otago Witness and the Wairarapa Daily Times in the late 1890s, having moved to Wellington with her husband, Malcolm Ross, who was beginning his career in the press gallery. Forrest Ross was involved in a famous incident in 1898, in which the Speaker ordered the Press Gallery (but not the Ladies' Gallery) to be cleared during a heated debate on the estimates, a stage in the consideration of the proposed Budget for that year. When members drew his attention to the fact that Ross was still present and taking notes, he ruled that the Ladies' Gallery was not part of his jurisdiction. ${ }^{23}$ Ross thus achieved a major scoop, the fruits of which were published in the Witness under the triumphant subheadings 'The Press Gallery Cleared-A Lady Correspondent's Special Report'. ${ }^{24}$ The incident received a lot of coverage; other papers commented rather enviously on the 'solitary woman correspondent' who had 'the monopoly of the proceedings'. ${ }^{25}$ The Otago Witness's report of the situation, which appeared separately from Ross's account of the debate but was perhaps also her work, was predictably more positive; under the sub-heading 'The Lady Reporter Scores', the Witness's correspondent wrote that ' $[t]$ he one lady reporter left in the gallery - who would have been ejected if she had been in the press gallery-thereupon smilingly took up her note-book in blissful consciousness that she had a monopoly of the news for the time being .... ${ }^{26}$

Ross was also responsible for another, quite different, parliamentary column. In 1898, the Weekly Press began publishing 'Peeps at Parliament', a column by 'Pamela'. ${ }^{27}$ 'Peeps at Parliament' followed in the English tradition of the parliamentary sketch. Although it covered the debates in some detail, its focus was on the experience of attending the House. The column ran till 1910, and was accompanied by cartoons from the beginning of the 1909 parliamentary session. The approach adopted in 'Peeps at Parliament' made Ross a very successful reporter. The MP William Downie Stewart later wrote:

Her articles as a Parliamentary correspondent were always bright and witty, and I have known Members of Parliament who sought her acquaintance in the hope that their speeches might find favourable comment in her weekly review of Parliament as seen from the gallery. One country member said to me, 'My electors don't read Hansard, but they do read Mrs. Ross's comments, so I hope they will regard me as a rising statesman'. ${ }^{28}$

The fourth important antecedent to Robin Hyde in the Ladies' Gallery was Stella Henderson. Henderson began working as a parliamentary correspondent for the Lyttelton Times in 1898. She was already a figure of renown; her desire to practice law had led to the 1896 Female Law Practitioners' Act, a piece of legislation specifically designed to allow her to be admitted to the bar as New Zealand's first female barrister and solicitor. It was perhaps not surprising that Henderson was at the centre of a controversy about the conditions under which women reporters worked in the House. In September 1897, a section of the Ladies' Gallery had been set aside for women journalists, partly to forestall requests that the Press Gallery be integrated. ${ }^{29}$ In mid-1898, when Henderson came to Wellington to begin work, her editor at the Times requested that the paper's seat in the gallery be made available to her. ${ }^{30}$ It was generally acknowledged, as the Wanganui Herald pointed out, that the journalists working from the Ladies' Gallery operated under enormous disadvantages in terms of comfort, audibility and note-taking. ${ }^{31}$ Many newspapers strongly supported the right of Henderson and the other three women reporters working at the time to make use of the press gallery; the Otago Witness asked archly, '[w]hat is a press gallery for unless to accommodate press representatives? ${ }^{32}$ Others mocked the women's pretensions; a satirical poem, 'The Lay 
of the Last Reporter', imagined a dire future in which women so dominated the press gallery that male journalists would be unable to work there. ${ }^{33}$ In an unpopular decision, the members of the gallery voted 11-5 against Henderson's admission, asking instead that better facilities be provided in the Ladies' Gallery. ${ }^{34}$

Boddy and Matthews suggest that 'a female tradition was not easily available to women writers and journalists of the twenties and thirties', yet these four reporters, and the controversies and successes that surrounded them, cast long shadows. ${ }^{35}$ By 1925 , women's parliamentary journalism in New Zealand already had acknowledged pioneers and a history of popularity with both editors and readers. It also had identifiable stylistic traits, which exerted a crucial influence on Hyde's style, as I will discuss in more detail shortly. But she was also a product of the particular conditions of the 1920s, as she sought to establish a role for herself in the crowded market for parliamentary journalism.

\section{The 'Novitia' Columns and New Zealand Parliamentary Journalism in 1925}

By the 1920s, the major New Zealand newspapers divided their parliamentary coverage into two categories. First, each paper printed long articles that focused on particularly significant debates. While not presented as verbatim accounts, these articles gave very full (if not always even-handed) coverage of the day's major business. Most papers had one regular column that covered parliamentary business, with further articles on single issues if they were of particular public interest. The centrality of parliamentary business was obvious in the names of these heavier columns; the New Zealand Times's 'The Legislature in Session', the Dominion's 'Parliament in Session' and the New Zealand Herald's 'Parliament' and 'Debate in the House' all suggested a focus on political business.

This material was supplemented, however, by another type of column from press gallery correspondents which, to varying degrees, made light of parliamentary affairs. This second tier of more light-hearted columns foregrounded the experience of attending and watching Parliament, as was evident from their titles: the Auckland Star's 'From the Gallery'; the New Zealand Times's 'House and Lobby: Parliament in Paragraphs'; the Christchurch Sun's 'Looking Down: Notes from the Gallery', and the Dominion's 'In Chamber and Lobby'. A third tier of occasional articles was clearly positioned to capture readers interested in intrigue, such as the Dominion's 'Gallery Whispers' and the Auckland Star's 'Parliamentary Gossip'. Some pieces highlighted a feature of life in Parliament, such as a piece titled 'Strange Bedfellows', which described the way the 'Oldest Gallery Hand' could tell the identity of a snoring MP without looking down at the floor of the House, or columns on Black Rod (the name given to a ceremonial role played by one of the officers of Parliament), the Parliamentary Library, and the Coat of Arms, which appeared in the Christchurch Sun. ${ }^{36}$ There were also columns, like The Press's 'Obiter Dicta', that commented on Parliament based on the reports in the newspapers and in Hansard. This approach to covering the House in the early 1920s meant that readers had an almost bewildering array of choices of how to consume their parliamentary news, even within the pages of a single paper. It was this environment, a combination of serious political business, journalistic variety and irreverent humour, that Hyde entered in 1925.

In order to understand some of the connections to the work of writers like Suisted, 'Birds' Eye,' Ross and Henderson, it is necessary to get a flavour of Hyde's style as a reporter, especially as her parliamentary reportage is not nearly as familiar to readers of New Zealand literature and criticism as her novels, poetry, and even some of her feature journalism. The richest source of material is the 'Peeps at Parliament' column that she composed for the Dominion in 1925. As I have argued elsewhere, although her column superficially appears to be a lady's view of the House, Hyde did not always construct herself as a woman speaking to women in 'Peeps at Parliament'. Her readers were often 'ladies and 
gentlemen' or 'Messieurs et Madames [sic]'. ${ }^{37}$ Sometimes she would make it clear that she was speaking to her male readers, describing them going 'home to your wives' or explaining that 'I did hope that ... I'd be able to say to you, "Gentlemen, the Address-in-Reply has quietly passed away". 38 At other times she deliberately addressed women, requesting to 'speak in private, for just one moment, to the feminine section of the community' or asking 'the feminine section of the community, as woman to woman, just one simple and straightforward question. Do you, or do you not, know what an Auditor-General is? If you don't, you have no real reason to blush for yourselves. I didn't myself, until this afternoon' ${ }^{39}$ The implication of these comments was that she did not expect to be read by women alone. And while she generally adopted a female persona, occasionally she would take on a male voice, wondering why politicians thought that people like her would 'squander our surplus incomes (if we had any) on new hats for our wives, new steam-engines and submarines for our infant phenomenons, and new-let's think of something sensible — new tobacco-pouches for ourselves ...' ${ }^{40}$ This tendency to shift genders was not always simply a stylistic device but also became, briefly, a factor in the production of the column; as she later noted, she allowed one of the Labour MPs to write an article for her when she was sick, so that Novitia became, temporarily, the pseudonym of a male author. ${ }^{41}$

While Novitia often spoke to male readers and occasionally assumed a male voice, she frequently drew attention to the fact that she was reporting from the Ladies' Gallery. The first 'Peeps at Parliament' column was subtitled 'Novitia" in the Ladies' Gallery', and the conditions under which the women reporters worked were a constant theme of the pieces that followed. She described the Private Secretary's room as 'beautifully fitted out with big, deep, comfortable sofas-the kind that Mr. Speaker has, upon our frequent solicitations, so thoughtfully provided for the occupants of the Ladies' Press Gallery. (N.B. That last sentence was intended to be ironic.) ${ }^{42}$ The contrast between the conditions afforded to male and female reporters particularly stung her; she told her readers:

... several of the more frequent visitors to the Ladies' Gallery are prepared to produce X-ray plates and medical certificates showing that their spines have become permanently deformed since the first fateful day when they entered the House. I wonder if the S.P.C.A. could be induced to give the matter a little serious consideration? Do you know that, actually, in the Ladies' Press Gallery, we sit on benches! Over in the Press Gallery occupied by the Lords of Creation, they appear to recline on divans. ${ }^{43}$

This complex blend of male and female identities for herself and her readers was paralleled by a mixture of roles as an insider and an outsider. The pseudonym 'Novitia' beautifully captured the balance between knowledge and naïveté; Hyde presented herself as someone who was on her way to understanding the norms of Parliament, not yet a veteran but by no means excluded from the House's proceedings. In fact, her primary target audience appeared to be the 'alternative empire' of women, children and Māori and other marginalized people that Chris Price has discerned in Hyde's fiction. ${ }^{44}$ This tone of growing familiarity permeated her reports in the Dominion, although the boundary between innocence and experience was always remarkably fluid. Sometimes she and her readers were 'we uninitiated folk' while she herself was an 'uninitiated outsider'. ${ }^{45}$ Elsewhere she demonstrated, rather facetiously, that she was becoming familiar with Parliament's arcane ways, commenting 'I suppose there are dwellers in heathen darkness - even in this comparatively civilised land of ours-who have never even heard tell of an Imprest Supply Bill? H'm. I thought as much. To be perfectly frank with you - just for this once-I hadn't myself until half an hour ago'. ${ }^{46}$ She could thus mock Parliament while establishing herself as a knowledgeable guide to its processes, joking that her readers 'might think that a Bill, good or bad, visits the House once, 
is thought over, talked over, worked over, and finally accepted or rejected. That just shows your charming innocence. Once upon a time, I believed the same myself. Ah, me! ${ }^{47}$

In particular, Hyde stressed her gradual initiation into the language of the debating chamber. At first her approach was to suggest a mock naïveté, as she commented 'I don't quite know just what a caucus is - some kind of tangi or war-dance, isn't it?-but I do wish I'd seen one'. ${ }^{48}$ Later she drew attention to her familiarity with Parliamentary patois, saying '[i]t would be quite in keeping with the finest traditions of the House (I hope you notice how I'm picking up these neat little Parliamentary phrases) ... ${ }^{49}$ Later still she simply peppered the column with such phrases without drawing attention to them, offering 'a question to put on the Order Paper, or, by the consent of the House, we will put it without notice', or proposing that ' $[\mathrm{t}]$ hese are degenerate days, dear readers, and for that reason I have a proposal to put before the House (that is, if Mr. Speaker doesn't mind my omitting to give notice of motion), which may, I believe, tend to have a decidedly elevating condition on Parliamentary life if once carried into effect' ${ }^{50}$

Alongside the coverage of the debates was a wide variety of imaginary scenes. Humorous conversations with invented characters (both human and animal), reveries about what the nineteenth-century Parliament must have been like, and descriptions of her own daydreams while in the House all featured. ${ }^{51}$ The fictional air of parts of the column was further enhanced by Hyde's frequent use of literary allusion; lines from Browning, Tennyson, de la Mare, Wordsworth, Dickens, Shakespeare, Lewis Carroll and, in particular, Kipling and Coleridge, all featured in her coverage.

\section{Hyde in Parliament After 1925}

'Novitia's approach to reporting had fitted neatly into contemporary norms, but 'Peeps at Parliament' was not Hyde's only attempt at parliamentary journalism. Her three reports for the Ladies' Mirror, published between August and October 1928, reveal the way in which her earlier style in the Dominion matured and adapted without losing its essence. The initiation process that had dominated the earlier column was well and truly over. The new column for the Mirror sensibly assumed an entirely female readership in its use of the term 'mesdames' in preference to the mixed audience that was implied in the 'Peeps at Parliament' reports of $1925{ }^{52}$ While the readers themselves were portrayed as outsiders in parliamentary business, to whom Hyde offers to attempt to glean 'such wit and wisdom as is not above feminine heads', the author seemed more of an insider. ${ }^{53}$ Hyde's column for the Mirror was titled 'From the Gallery', a heading which neatly elided the difference between the Ladies' Gallery and the Press Gallery and thus not only obscured the gender of the author, but moved her a step closer to the centre of the action. Moreover, 'Novitia' had been replaced by 'Krino', the Greek word for judge, implying not only a much better-informed and more discerning commentator, but one who was also possibly male.

The column's tone was still playful and extremely amused by parliamentary business, but its author subtly stressed her familiarity with the operations of the House. On the first noconfidence motion that she witnessed during her work for the Mirror, Hyde noted:

One or more happens along every session, blithely opened by the Opposition, who, when the Government moves "that this House present a respectful address-in-reply to the speech from the Throne," promptly produces some snaky little amendment, deleting all the words after "that," and instead informing His Excellency, but in more Parliamentary terms, "that this Government is the bunk." Upon this motion, members may discourse for a full hour, instead of their customary half. ${ }^{54}$

When the House began its usual practice of eulogizing members who had passed away since the previous session, Hyde informed her readers: 
A formal and rather interesting feature of the first day's session's doings is the holding of a sort of tangi, at which departed members and friends are duly honoured by the House, and the "regrets" later transferred to widows or relatives likely to appreciate them. Needless to say, the ceremonies have been, as far as possible, stereotyped, but there still remains a touch of romance and more than a touch of pathos. The Prime Minister arises and delivers himself of little biographies, dealing with each departed comrade's life and works. ${ }^{55}$

This reporter was evidently used to witnessing the House in action and had attended several sessions. The tone of the remarks was knowledgeable and sought to establish credibility with the Mirror's readers. Initiation still had its place, but Hyde was now on the side of the initiates.

Hyde's final piece of parliamentary journalism was a one-off article for the New Zealand Observer, based on a trip to the gallery while visiting her family in Wellington in 1932. Krino, like Novitia, had disappeared; this article was published under Hyde's real name, Iris Wilkinson. The decision to publish under her own name seems logical; a persona was not as necessary for a single piece as for a column, which needed to build up an audience. But there are other layers of interpretation in this choice. It was an expression of authority and confidence to eschew not only some of her cuter pen-names, but also her most common nom-de-plume. Most of her articles for the New Zealand Observer had in fact appeared under the byline 'Robin Hyde'. Temporarily discarding that pseudonym meant separating this piece of parliamentary writing from the rest of her contributions to the paper. It also meant shedding the gender ambiguities of 'Robin'. Unlike the pieces by Krino in the Ladies' Mirror, the article of 31 March 1932 was definitely emanating from the Ladies' Gallery, since there was nowhere else that Iris Wilkinson could sit; unlike the pieces by Novitia in the Dominion, there was no need to create a coy disguise of naïveté.

The article itself bears out this assumption of a mature and confident tone. Krino had clearly been to the House over several sessions, but Iris Wilkinson took an even broader view. The House still has 'a little of its old serene atmosphere', and '[t]he same orderlies who haunted the corridors and entrances ten years ago are there to usher visitors to the Galleries'. ${ }^{56}$ She appears very familiar with the protagonists in the House, describing them as if she had known them when they were much younger men. Harry Holland 'walks out with the slight, jerky limp which is a relic of an illness that kept him on crutches for years', while the Speaker's face is '[a] little thinner, a little more deeply lined' ${ }^{57}$ The Labour MP William Parry has changed his mode of debate, using 'finer weapons than came to the Parry hand in the old days'. ${ }^{5}$

Hyde also projected a long-term familiarity with the political issues under discussion. The controversial amendments to the Arbitration Act are described as constituting 'some of the most important and contentious legislation of a generation ... Thirty years ago, under a Prime Minister dead and gone, legislation was passed, and the Arbitration Court stood foursquare. In 1932, with courage oozing out of empty pockets, we set to work to destroy our few claims to progressiveness'. ${ }^{59}$ Remnants of the past are very much in evidence; the gallery reserved for members of the Legislative Council is depicted as full of ghosts, and the piece ends with a glance back to the earliest days of representative government in New Zealand:

Downstairs, in the main corridor, a portrait of Mr. Forbes [the current Prime Minister] has taken its place in company with a long shadowy line of bygone Prime Ministers. The photographer has done a good job of work: life-size, heavy-jowled and not unimpressive, the Prime Minister stares soberly across at Sir Julius Vogel. And all along the corridor, haughty old men with Dundreary whiskers and enormous collars stare unwinkingly back at him. ${ }^{60}$ 


\section{Hyde, Her Foremothers and Her Contemporaries}

Hyde's parliamentary journalism across these seven years displays a host of stylistic and professional techniques that can be seen reflected in some of her more literary writing. But as Mary Paul argued some time ago, it is no longer necessary to argue for the importance of Hyde's work; the remaining scholarly frontier is instead to develop a better understanding of the various contexts in which she worked. ${ }^{61}$ Paul's work has illuminated some of the social and political contexts, but what I would like to focus on here are the historical and cultural contexts of women's parliamentary journalism, both leading up to Hyde's time in the gallery and operating around her as she reported. The journalism produced by Laura Suisted, Forrest Ross, Birds' Eye, and Stella Henderson establishes some patterns in women's parliamentary journalism, often complex and contradictory, that were potentially influential in Hyde's conception of her role. The first set of patterns relates to the presentation of the journalism. The titles of many of the early women reporters' columns appeared to send coded messages about the status of the author and, perhaps, that of her readers. 'Jottings', 'Notes', 'Peeps'these terms all imply a light-hearted, casual, perhaps even trivial approach to parliamentary journalism. Birds' Eye's column was titled 'Our Legislators' but often featured a sub-heading that contained these elements: 'Stray Notes and Dialogues' or 'Snap Shots'. ${ }^{2}$ Hyde's 'Peeps' were overtly linked to Ross's 'Peeps,' but also to this wider tradition of situating women's parliamentary journalism in a space that was, at least outwardly, depicted as superficial.

Hyde's use of a pseudonym, and her various personae with their complex mix of deference and authority, drew on the history of women's parliamentary reporting in New Zealand. Her predecessors all adopted split-personae, indicated by different pseudonyms, for their various reports. Suisted's choices set the pattern. 'The Scribbler', which she used in 1884, implies a skittish, amateur writer. 'Pearl Pen', the name she adopted in 1886-87 and 1890 , is somewhat more authoritative in its direct claim to the implement of writing but also more obviously gendered; the journalist sounds genteel and decorous. Meanwhile, although the identity of Birds' Eye is unknown, she too developed more than one persona in her columns. During her short tenure for the New Zealand Graphic and Ladies' Journal in 1893, Birds' Eye produced two columns under the name 'Biddy Malone', complete with phonetic spelling for Biddy's Irish brogue. Ross's Otago Witness columns appeared with no byline and under fairly authoritative headlines, suggesting that she was keen to be treated as any member of the press would have been and to avoid the creation of a conscious persona that was common to women journalists. It would not have been clear from the articles themselves that the author was not a member of the press gallery. Her 'Peeps at Parliament' articles for the Weekly Press, however, provided an outlet for a different approach. Both the title of the column and the female pseudonym 'Pamela' conveyed the outsider status of the woman reporter who was definitely not in the press gallery proper. ${ }^{63}$ Henderson was 'Our Correspondent' for the Lyttelton Times, a non-descript persona suggested legitimacy and gender-neutrality, but with the political undertone that it was the fact that she was 'Our Correspondent' that had been used unsuccessfully to push for her admission to the Press Gallery.

As well as the overlaps in terms of title and pseudonym, the tone of Hyde's reports also sat neatly alongside that of earlier women reporters. Birds' Eye particularly resembled Hyde in the way she joked about the triviality of the parliamentary scene. One of her 'Our Legislators' columns was subheaded 'Side Lights on Themselves and Their Little WaysSarcastic Snap Shots from the Ladies' Gallery', a title that redefined the Ladies' Gallery as a place of power and authority compared with the childish antics on the floor of the House. ${ }^{64}$ This particular column was accompanied by a cartoon that depicted 'Birds' Eye' as a 
lepidopterist examining a specimen through a magnifying glass. The butterfly $-\mathrm{a}$ member of the House of Representatives complete with wings - is labelled 'M.H.R. (common variety)'.

Other techniques, such as the mixture of fact and fiction and the use of literary allusions that often characterized Hyde's reports, linked her work with that of her predecessors. Ross, in particular, had utilized these approaches. One of her pieces, 'In the Ladies' Gallery', consisted of an imaginary scene in the Ladies' Gallery, complete with stage directions. ${ }^{65}$ Other reports by Ross incorporated Shakespeare, Kipling, and the occasional nursery rhyme, while Suisted peppered her columns with lines of verse, some of which she composed herself on parliamentary subjects. ${ }^{66}$

The idea of the lady reporter as an outsider undergoing initiation, which Hyde developed into a central theme of her Dominion reports, had some parallels in these earlier examples. Suisted commented that the experience of reporting Parliament had quickly made her 'a coldly critical observer of our worldly legislators, whom in bygone times I was wont to deem perfect oracles of eloquence and wisdom combined' ${ }^{67}$ Similarly Ross noted that just one year earlier, 'I used to fondly imagine that a member who was asked to leave the Chamber with the shadow of a censure over his head would be cast into some dungeon, with an orderly on the mat outside the door. The older we grow the more illusions we lose ${ }^{68}$ The idea that women - whether as reporters or as readers-might actually take pride in their outsider status often shone through. Suisted asserted her credentials by distancing herself from the political world, suggesting that "Pearl Pen" ..., although holding discretionary power to deal with matters grave or gay, as errant fancy or sober circumstances may direct, does not at the same time profess to be a very wise or profound politician'. ${ }^{69}$ Ross joked of one MP that ' $[\mathrm{t}$ ]o us mere ignorant women, half of his remarks seemed unparliamentary, but we must have been wrong, for he was not interrupted by the Acting-Speaker'. ${ }^{70}$ Birds' Eye's successor as parliamentary correspondent for the New Zealand Graphic, who might have been male but was certainly addressing a female readership, wrote under the pseudonym 'A Mere Outsider' and got considerable comic mileage out of the idea that Parliament was a place too mysterious for ordinary sensible people. ${ }^{71}$ But Ross and Suisted were also quick to place themselves in the roles of knowledgeable insiders who could help train 'the eye of the uninitiated'. ${ }^{72}$ Although this intermediary status-sometimes an insider and sometimes an outsider-did not dominate their columns the way it did Hyde's, it was a noticeable feature of the way they approached their role.

A more sophisticated example of this technique can be seen in Birds' Eye's use of a secondary persona, the naïve observer Biddy Malone, an Irish domestic servant who was visiting Parliament with her friend Polly. The conversations between Biddy and Polly about 'Parleymint' highlight the gap between the views of parliamentary outsiders and insiders, with the added twist that Polly's insider status is largely self-declared and thus also mocked. When Biddy comments "'shure oi thought 'twas here they were sint to make laws, and look after the connthry's bizness; not to be foighten' over binches, an' which will sit in the sun", Polly replies that "that ony shews how little ye know". 73

Birds' Eye was also particularly strong in her mockery of parliamentary language. Part of Polly's credibility in Molly's eyes derives from the fact that she is 'vurry smart wid her turrms'. ${ }^{74}$ Birds' Eye came back and back to the oddities of this language, joking that until one is used to being at the House, the methods of the place are confusing. A stranger from the blessed verdancy of the country is apt to be misled. He never dreams of double shuffle, but takes all he hears for gospel, and fancies all things what they seem, than which there is no greater fallacy. As a matter of fact NO ONE HERE CALLS A SPADE A SPADE, at least not after his first session. When an M. H. R. says a spade, he means a hoe, and vice versa ${ }^{75} \mathrm{On}$ one occasion, she also included some examples of invented parliamentary discourse to satirize its pomposity, before commenting: 'Think of the frightful strain upon all the faculties 
involved in standing round a roaring fire with a cigar in one's mouth which has to be removed at intervals to allow of the freer flow of such "burning words" as the above. What's standing at a wash tub, or stewing over a cooking stove in comparison? ${ }^{, 76}$

Birds' Eye's rhetorical question hit upon an important element in early women's parliamentary journalism in New Zealand. There was a persistent sense in these articles that women could make a better job of running the country than their male compatriots. In one of her reveries, Hyde had imagined an alternative all-female legislature which would 'show the exorbitantly dear old gentlemen of the House just how exciting a Parliament can be when it really tries'. ${ }^{77}$ Birds' Eye achieved a similar effect in a column that consisted entirely of an extremely well-informed conversation between the women in the gallery about the issue of Prohibition. ${ }^{78}$ No coverage of the House's deliberations was included in this column, highlighting the notion that women's discourse on the subject could easily replace (and perhaps surpass) the debates that occurred in Parliament. In this column, the MPs take the role of the crowd in the gallery and appear as background observers, occasionally laughing at some minor point of their own, in a manner that suggests an exchange of roles with the occupants of the Ladies' Gallery.

This strain of journalism often referred to the energy that women might bring to reforming Parliament. Hyde's suggestion that women could 'have the country and world spring-cleaned in a year' had a precedent in one of Birds' Eye's columns, published after a debate on enfranchising women, which depicted two women sweeping up tiny MPs off the floor with brooms labelled 'Women's Vote', in order to dump them in a dustpan labelled 'Oblivion'. ${ }^{79}$ In an aside that is particularly revealing about the role that women could play as both legislators and journalists, Hyde remarked that ' $[\mathrm{w}]$ hat Parliament really needs is, among other things, somebody with an inventive mind who would take everything in hand and disorganize it with a view to developing its more picturesque possibilities. I don't say that, if sufficient temptation were placed in my way, I mightn't consider taking on the job myself ${ }^{80}$ This view was shared by some of her predecessors, including Ross, who felt that ' $[\mathrm{t}]$ here seems to be an epidemic of limpness and depression affecting some of our legislators ... They really want shaking up, one energetic woman in the gallery declared, and had the powers that be permitted it I feel certain she would have done it, with the utmost satisfaction'. ${ }^{81}$ Some of Hyde's most characteristic, and potentially most subversive, effects thus had strong links with previous generations of women reporters. A style had been established by these pioneers which remained influential in the 1920s. Hyde use of these techniques demonstrates her knowledge of the legacies of her predecessors and her understanding of the way in which her 'Peeps at Parliament' could join the ranks of earlier popular columns.

While the tradition of women's gallery journalism was a significant factor in Hyde's style, there is a second significant context as well. Her first foray into parliamentary reporting also needs to be read alongside the work of other journalists who worked in the House in 1925. Sketch writers produced the impressionistic and often light-hearted accounts of Parliament that were published alongside the weightier reports in the newspapers, and Hyde seems to have been one of only two women reporters whose job it was to compose such sketches when she worked for the Dominion. The other was Nellie Scanlan, who wrote for the New Zealand Free Lance. Like Hyde, Scanlan was destined for a high-profile career in the world of letters, as a prolific journalist who reported from all over the world, but bestknown for the 'Pencarrow' tetralogy of popular novels.

The characteristics of Scanlan's reports demonstrate how Hyde adjusted to the requirements of contemporary women's sketch writing. Each woman's column had a title that suggested a mixture of deference and authority. Hyde's 'Peeps at Parliament', as I have noted, sounded timid but had behind it Ross’ pedigree. Scanlan's column was initially titled 
'Bubble and Squeak', a label that seemed to characterize her own thoughts as minor and passing, but which clearly referred to the behaviour of the MPs, as her sub-heading, 'What They are Doing in Parliament', made clear.

As well as conforming with the apparatus of columns like Scanlan's, Hyde also captured many of the details of Parliamentary business that caught the eyes of her fellow reporter. Scanlan, too, was scathing about the general abstruseness of parliamentary business, noting that '[a] direct answer to a direct question and a courteous answer to a courteous question are not quite unknown, but the game of politics would not be the complex puzzle it is if a straightforward question always met with a straightforward answer. It would reduce the session to the low level of an ordinary business board meeting, and that would be ridiculous. Look at the unemployment it would cause. Hansard would become a slender volume; the Government Printing Office would be reducing its staff, and there would be many people out of a job'. ${ }^{82}$ Like Hyde, who had said of the Budget debate that she 'got lost somewhere about sub-section Q, clause 96, of the Bill, and never found myself again', Scanlan tried to convey the sheer complexity of the House's deliberations on the Budget:

With a splendid effort you seized upon a figure - the year's revenue. It is much easier to retain amounts learned through the eye than through the ear. Mentally, you clutched that twenty-eight million six hundred and forty-three thousand, and held it until the expenditure of twenty-seven million three hundred and ninety-nine thousand two hundred was superimposed upon it, followed by the fact that the revenue was greater this year by six hundred and eighty-two thousand six hundred and thirty. By that time your mind had ceased to work. It was clogged above the million mark. ${ }^{83}$

The general misbehaviour of parliamentarians that had caught Hyde's eye also came through vividly in Scanlan's writing. Hyde had joked about a room marked "Strictly Private" into which the public must not come. I was told, in a reverential whisper, that it was the Parliamentary Holy of Holies - the inner sanctum where they withdraw to commune with their deepest thoughts. From it issued forth a faint clicking-probably a typewriter-but which sounded to my inexperienced ears oddly like the musical chinking of billiard balls. ${ }^{84}$ Scanlan, meanwhile, observed that, on one occasion, 'one member was working out a new and absolutely reliable system for backing horses. Two others were turning the pages of the "Sketch," or was it "Eve?" but pretty ladies smiled back from between its covers. Another was sadly counting a bunch of totalisator tickets-duds'. ${ }^{85}$

It is not clear whether Hyde was directly influenced by Scanlan. She would certainly have come into contact with her, as they were amongst the few women reporters in the House, and it is possible that Scanlan is the woman Hyde referred to as 'Bold Herminius, because she sat on my right hand and kept the bridge with me'. ${ }^{86}$ But it seems more likely that she was simply in tune with the kind of reports that other journalists were producing in 1925.

\section{Conclusion}

Hyde's thorough assimilation into the norms of women's parliamentary reporting raises some important questions about her work in the gallery and what it might tell us about her journalism's place within wider cultural debates about style, gender and authorship. Given her apparently successful integration into the world of parliamentary journalism in 1925, why did Hyde find it so difficult to gain another post as a reporter in the House? Why did a suggested role as parliamentary correspondent for the Christchurch Sun in 1928 fall through? When she decided to take a press pass to the Ladies' Gallery that year in any case and 'to try to hammer the "Free Lance" \& perhaps one or two city dailies into a comatose or mesmerized 
condition, under influence of which they'll accept my articles', why did these papers not accept her work, especially the Free Lance, which had already shown a preference for this sort of reporting when it hired Scanlan? ${ }^{87}$ Why did Hyde's parliamentary journalism peter out into three pieces for the Ladies' Mirror in late 1928 and one further sketch for the New Zealand Observer in 1932 ?

One answer is that the mid-1920s marked the last hurrah for the style of parliamentary journalism at which Hyde excelled. Scanlan wrote another column, 'Facing Mr. Speaker's Chair', for the New Zealand Free Lance in 1926 and reported on the opening of Parliament in 1927 before the column ended and the Free Lance stopped all detailed parliamentary coverage. The major daily papers continued to print occasional columns of this sort, such as the Dominion's 'Notes and Gossip from Lobby and Chamber', but there was no longer any demand for a regular sketch.

Moreover, the idea of a distinctly female parliamentary journalism was potentially becoming dated. It had been more than 15 years since Forrest Ross had ended her 'Peeps at Parliament' column, and the notion of Ladies' Gallery journalism as a specific sub-genre now seemed to belong to the previous century. Several publications sent women to Parliament to report on the glamour of Opening Day, but none of the other major periodicals published a column that was specifically styled as being 'From the Ladies' Gallery' by 1925 . The only other woman reporting from Parliament at this time that we know anything about, Nelle Scanlan, was valued by her employers because of her established reputation as a journalist, not her gender, and her columns did not reflect a particularly feminized approach to parliamentary business. If Hyde was the victim of such an impression in the years after 1925, it is somewhat unfair; as I have argued, her work for the Dominion largely acknowledges this problem, as she plays with the expectations about such ladies' parliamentary columns in a manner that suggests that she knew they were already a little passé.

Another factor, paradoxically, is that Hyde's writing sat somewhat uneasily between the sketches and the regular reports. Her articles read in part like the general overviews of Parliament and its foibles that Scanlan was producing, but such a style suited a weekly paper, such as the Free Lance, much more than the daily account that she was required to provide for the Dominion. While there were clear themes in her reports, they also had the flavour of bulletins from the House, composed under much the same conditions that governed the regular reporting from the Press Gallery. She had included, for example, more than 50 apparently direct quotes from MPs in her 'Peeps at Parliament' columns. Some of the phrases she captured closely parallel what was recorded in Hansard; others do not appear in Hansard but were also reported by members of the Press Gallery. ${ }^{88}$ In addition, she used some of the techniques that Pat Lawlor outlined as standard press gallery procedure, such as interviewing MPs before the House sat or in between the afternoon and evening sittings. ${ }^{89}$ These techniques, combined with her own interest in the debates, led to the inclusion of much more specific content from the speeches than was normal in such sketches.

While the 'Peeps at Parliament' columns show that Hyde understood exactly what the papers were expecting in 1925, her later sketches for the Ladies' Mirror and the New Zealand Observer need to be read as a kind of anachronism, a harking back to a style of journalism that had largely disappeared, and for which there were not many obvious parallels by the late 1920s and early 1930s. Such an approach probably sank her career as a parliamentary reporter, but it demonstrated an acute awareness of the traditions of the Ladies' Gallery. It seems to be an approach that was not so much unconventional and modern as deferential and traditional, yet that deference was owed not to Parliament itself but to the women who had come before and the talented company in which she found herself in 1925.

Hyde's parliamentary journalism must be resituated in a tradition derived from nineteenth-century women's reporting, not simply because the influences are so clearly 
present in her work, but because such a resituation adds an important additional layer to the contentious dismissal of her work by the male cultural nationalist authors of the 1930s. Hyde was frequently depicted as straying too close to the Georgian style deplored by such authors, including Denis Glover, A.R.D. Fairburn, Frank Sargeson and Allen Curnow, however much they expressed a grudging admiration for her work and a hope that she would move away from these influences. ${ }^{90}$ It is not likely that these writers exerted a particular influence on the way women's parliamentary journalism was received; rather, as Lawrence Jones has proposed, a disdain for the Georgian was 'in the air' in the 1930s. ${ }^{91}$ Yet Stuart Murray convincingly suggests that 'there is much within the material produced during the 1930s that, for all its modernity, casts its eye back to the nineteenth century. ${ }^{92}$ These two cultural contexts, one which stresses the ongoing connections to the nineteenth century and one which emphasises how these were being challenged, are vital to understanding Hyde's parliamentary journalism. The cultural nationalists' disdain for Georgianism was not limited to literary production; journalism was also critiqued and Hyde was one of the chief targets of the scorn poured on a realm that took in both fictional and non-fictional manifestations of the Georgian style. Glover's famous attack on Hyde in the poem 'The Arraignment of Paris,' which satirizes the circle of writers around Charles Marris, makes it clear that it is not just her gender but her journalism that he is mocking:

Among them, though, there's one who's fairly good

a desolated star, a Robin Hood

who ranges round among the greenwood trees

from classic style to rabid journalese,

who turns her pen from sonnet or from ballad

to gossip pars, or recipes for salad.

A pity she should lack a sense of humour;

if she is roused, beware! she's like a puma

this lassie who is never quite the same

without her daily teaspoonful of fame.

But let her be-she's still a giddy gel;

if she keeps on she should do fairly well. $(172-183)^{93}$

Hyde's journalism, the source of her 'daily teaspoonful of fame' is thus implicated in Glover's critique of her writing style, bringing it into a wider debate about the merits of retaining links to the nineteenth century in New Zealand literary productions.

Hyde was entirely of her time in looking back to an era that was in the very near past as she wrote and in finding inspiration from writers (particularly women writers) who had flourished then. But the perishing of her ladies' gallery reporting is equally a product of its moment, as New Zealand literary culture forcefully rejected the terms on which such legacies were constructed. Hyde's parliamentary journalism should thus take its place as one of the test cases for the problematic emergence of a New Zealand literary voice.

\footnotetext{
${ }^{1}$ Derek Arden Challis Papers, MS-Papers 9110-144, 196-97, Alexander Turnbull Library (ATL), Wellington.

2 Ibid., 198.

3 Ibid., 200.

${ }^{4}$ A complete collection of Hyde's parliamentary reports, including both the Dominion column and her four later pieces, can be found in The Collected Parliamentary Reports of Robin Hyde, ed. Nikki Hessell, http://nzetc.victoria.ac.nz/tm/scholarly/name-404726.html.
} 
${ }^{5}$ Hyde to J.H.E. Schroder, September 7, 1927, Schroder Papers, MS-Copy-Micro-0662, Folder 3, Letter 1, ATL.

${ }^{6}$ Hyde later related that Coates had offered her the use of a car and chauffeur on late nights; see Robin Hyde, Journalese (Auckland: National Printing, 1934), 33-34.

${ }^{7}$ See Hyde to Schroder, April 5 - June 27 1928, MS-Copy-Micro-0662, Folder 3, Letters 6, 20, 21, and 23, ATL.

${ }^{8}$ See Hyde to Schroder, July 4, 1928, MS-Copy-Micro-0662, Folder 3, Letter 24, ATL.

${ }^{9}$ Robin Hyde, Disputed Ground: Robin Hyde, Journalist, eds. Gillian Boddy and Jacqueline Matthews (Wellington: Victoria University Press, 1991), 85.

${ }^{10}$ Ibid., $19,85,19$.

${ }^{11}$ Derek Challis and Gloria Rawlinson, The Book of Iris: A Biography of Robin Hyde (Auckland: Auckland University Press, 2002), 59.

${ }^{12}$ Ibid., 45, 61.

${ }^{13}$ Ibid., 59.

${ }^{14}$ John A. Lee to James Bertram, December 29, 1953, MS Papers 4995-1, ATL; 'M.L.S.', 'Via Vladivostok', Woman To-Day (1 March 1938), 284. Hyde might have had some influence on the latter remark, as she was an advisor to the paper's board; see Hyde, Disputed Ground, 30.

${ }^{15}$ Phillida Bunkle, Jackie Matthews and Linda Hardy, "Who is the Real Robin Hyde?," Broadsheet (January/February 1985): 25; Brigid Shadbolt, “'Grubby in the Eyes of the Respectable': The Epistolary Dialogue of Robin Hyde and John A. Lee," Journal of New Zealand Literature, 16 (1998): 35.

${ }^{16}$ Bunkle, Matthews and Hardy, 25; Hyde, Disputed Ground, 85.

${ }^{17}$ Annabel Cooper, 'Review of Disputed Ground: Robin Hyde, Journalist,' Women's Studies Journal, 8:1 (1992): 146; Press, November 30, 1991, 27.

${ }^{18}$ The major critical accounts of Hyde's literary work rightly stress these aspects. See for example Mary Paul, Her Side of the Story: Readings of Mander, Mansfield and Hyde (Dunedin: University of Otago Press, 1999), 127-78 and Michele Leggott, "Opening the Archive: Robin Hyde, Eileen Duggan and the Persistence of Record." in Opening the Book: New Essays on New Zealand Writing, eds. Mark Williams and Michele Leggott (Auckland: Auckland University Press, 1995), 266-93, especially 266-79.

${ }^{19}$ Nikki Hessell, "Novitia the Anti-Novice: Robin Hyde's Parliamentary Reports." in Lighted Windows: Critical Essays on Robin Hyde, ed. Mary Edmond-Paul (Dunedin: Otago University Press, 2008), 151-161.

${ }^{20}$ An excellent summary of the development of parliamentary reporting in New Zealand in the nineteenthcentury can be found in John E. Martin, The House: New Zealand's House of Representatives 1854-2004 (Palmerston North: Dunmore Press, 2004), 52-55.

${ }_{21}^{21}$ Ibid., 46, 57.

${ }^{22}$ Her obituary in the Otago Witness made this claim and Suisted herself wrote in 1888 that she had 'for some years occupied the unique position of being the only lady newspaper correspondent in New Zealand attending Parliament ... for sessional work'. See Otago Witness (OW), September 9, 1903, 3, and MS-Copy-Micro-0777$2 / 2$, ATL. Suisted was also the first woman to be admitted to the New Zealand Institute of Journalists. For biographical details, see Janet McCallum, Women and their Words: Notable Pioneers in New Zealand Journalism (Masterton: Fraser Books, 2009), 51-54.

${ }^{23}$ Mrs Malcolm Ross and Noel Ross, Mixed Grill (Auckland: Whitcombe and Tombs, 1934), 229.

${ }^{24}$ OW, September 15, 1898, 16.

${ }^{25}$ Evening Post (EP), September 8, 1898, 2 and North Otago Times, September 8, 1898, 2, respectively.

${ }^{26}$ OW, September 15, 1898, 19.

${ }^{27}$ The column occasionally appeared as 'Peeps in Parliament' rather than 'Peeps at Parliament', but I am using the latter term throughout for clarity's sake. McCallum suggests that Ross shared the column with the journalist Nellie Kelly, and that Kelly was actually 'Pamela', but this supposition cannot be corroborated because McCallum's reference to her source is incorrect; see McCallum, Women and their Words, 55.

${ }^{28}$ William Downie Stewart, Preface, Mixed Grill, n.p.

${ }^{29} \mathrm{EP}$, September 24, 1897, 6.

${ }^{30}$ Similar efforts to integrate the Press Gallery were underway in Britain around this time; see Michael Macdonagh, The Reporters' Gallery (London: Hodder and Stoughton, 1913), 11.

${ }^{31}$ Wanganui Herald (WH), August 22, 1898, 2. It is likely that this piece in support of the women's cause was either written or influenced by Margaret Bullock, a freelance parliamentary reporter who worked for the Wanganui Herald; see McCallum, Women and their Words, 54.

${ }^{32}$ OW, July 28, 1898, 3. Forrest Ross is possibly the author of this article. She was one of the other three women reporters; the identity of the remaining two is unclear, although it is likely that Bullock was also one of them.

${ }^{33}$ New Zealand Observer and Free Lance (FL), August 27, 1898, 10. 
${ }^{34}$ The Christchurch branch of the New Zealand Institute of Journalists proposed a resolution protesting against the gallery's decision, although the New Zealand Institute of Journalists ultimately supported it as long as women journalists were given access to equally good facilities. See WH, August 30, 1898, 2. The original resolution decrying the gallery's decision was seconded by Malcolm Ross, who is portrayed in 'The Lay of the Last Reporter' as 'full of glee' at the prospect of an integrated gallery. Reports criticizing the ban appeared in the OW, July 28, 1898, 3; WH, August 11, 1898, 2; WH, August 16, 1898, 2; WH, September 7, 1898, 2; and EP, August 17, 1898, 5.

${ }_{36}^{35}$ Hyde, Disputed Ground, 86.

${ }^{36}$ See respectively Dominion (DM), September 14, 1925, 10; Christchurch Sun (CS), June 27, 1925, 12; CS, July 30, 1925, 8; and CS, August 7, 1925, 8.

${ }^{37}$ DM, August 22, 1925, 8, and July 10, 1925, 5. The summary of Hyde's style in the 'Novitia' articles that I offer here is based on my chapter "Novitia the Anti-Novice: Robin Hyde's Parliamentary Reports".

${ }^{38}$ DM, July 24, 1925, 10, and July 16, 1925, 10.

${ }^{39}$ DM, July $31,1925,10$, and August 19, 1925, 10

${ }^{40}$ DM, July 1, 1925, 10, and July 31, 1925, 10.

${ }^{41}$ Hyde, Journalese, 38. Challis and Rawlinson suggest that the MP in question is probably Dan Sullivan, an exjournalist. However, as they go on to record, John A. Lee later confirmed that he had written a column for Hyde. See Challis and Rawlinson, The Book of Iris, 62, 665.

${ }^{42} \mathrm{DM}$, August 28, 1925, 10 .

${ }^{43}$ DM, August 15, 1925, 8. Writing to J.H.E. Schroder she asked 'shall we start a campaign for a better ladies' press gallery up at the House, window-breaking and orderly biting to be planks of our platform?' See Hyde to Schroder, April 5, 1928, MS-Copy-Micro-0662, Folder 3, Letter 17, ATL. She makes a similar point in Hyde, Journalese, 32-33.

${ }^{44}$ Chris Price, "The Childish Empire and the Empire of Children: Colonial and Alternative Dominions in Robin Hyde's Check to Your King and Wednesday's Children." in Opening the Book: New Essays on New Zealand Writing, eds. Mark Williams and Michele Leggott (Auckland: Auckland University Press, 1995), 49-50.

${ }^{45}$ DM, June 30, 1925, 10, and July 1, 1925, 10 .

${ }^{46}$ DM, June 30, 1925, 10.

${ }^{47}$ DM, July 15, 1925, 10.

${ }^{48}$ DM, July 3, 1925, 10.

${ }^{49}$ DM, July 27, 1925, 10.

${ }^{50}$ DM, August 22, 1925, 8, and September 3, 1925, 10.

${ }^{51}$ See for example DM, July 24, 1925, 10; July 3, 1925, 10; July 13, 1925, 10; and July 10, 1925, 10.

${ }^{52}$ Ladies' Mirror (LM), August 1928, 49.

${ }^{53}$ Ibid., 49.

${ }^{54}$ Ibid., 49 .

${ }^{55}$ Ibid., 49.

${ }^{56}$ The New Zealand Observer, March 31, 1932, 4.

${ }^{57}$ Ibid., 4

${ }^{58}$ Ibid., 4.

${ }^{59}$ Ibid., 4.

${ }^{60}$ Ibid., 4.

${ }^{61}$ Paul, Her Side of the Story, 151.

${ }^{62}$ New Zealand Graphic and Ladies' Journal (NZGLJ), July 29, 1893, 38, and August 26, 1893, 130, respectively.

${ }^{63}$ In 1909, Ross abandoned this pseudonym, producing her final session's worth of reports under the name 'Mrs Malcolm Ross', a name which again both was and was not her own.

${ }^{64}$ NZGLJ, August 26, 1893, 130.

${ }^{65}$ F. Ross and N. Ross, Mixed Grill, 234-37.

${ }^{66}$ See for example Weekly Press (WP), August 31, 1898, 42; WP, October 5, 1898, 44, and WP, September 28, 1898, 45; and OW, May 20, 1887, 14, and October 21, 1887, 14.

${ }^{67}$ OW, September 27, 1884, 21.

${ }^{68} \mathrm{WP}$, August 31, 1898, 42.

${ }^{69}$ OW, October 21, 1887, 14.

${ }^{70}$ WP, August 31, 1898, 42.

${ }^{71}$ See NZGLJ, July 7, 1894, 14-15; NZGLJ, July 14, 1894, 40-41; and NZGLJ, July 21, 1894, 56.

${ }^{72} \mathrm{OW}$, July 5, 1884, 27. See also OW, June 24, 1887, 9; and WP, August 24, 1898, 42, for examples of this approach to readers.

${ }^{73}$ NZGLJ, September 2, 1893, 155. 
${ }^{74}$ Ibid., 155.

${ }^{75}$ NZGLJ, August 26, 1893, 130.

${ }^{76}$ NZGLJ, September 16, 1893, 205.

${ }^{77}$ DM, August 15, 1925, 8. See also LM, August 1928, 49.

${ }^{78}$ NZGLJ, September 9, 1893, 176.

${ }^{79}$ DM, July 3, 1925, 10; and NZGLJ, September 16, 1893, 204.

${ }^{80}$ DM, July 22, 1925, 10.

${ }^{81}$ WP, August 24, 1898, 42.

${ }^{82}$ FL, July $29,1925,32$.

${ }^{83}$ DM, July 29, 1925, 10; and Scanlan, "Bubble and Squeak," FL, July 29, 1925, 32.

${ }^{84}$ DM, July 13, 1925, 10.

${ }^{85}$ FL, July $15,1925,31$.

${ }^{86}$ DM, July 17, 1925, 10. The allusion is to Thomas Babington Macaulay's poem 'Horatius'.

${ }^{87}$ Hyde to Schroder, June 27, 1928, MS-Copy-Micro-0662-1, Folder 3, Letter 23, ATL.

${ }^{88}$ DM, July 17, 1925, 10. The comments on the 'petrified man' were not captured in Hansard but were certainly uttered, since they can also be found in EP, July 16, 1925, 6.

${ }^{89}$ Pat Lawlor, Confessions of a Journalist, With Observations on Some Australian \& New Zealand Writers (Auckland: Whitcombe \& Tombs, 1935), 70-80. See for example DM, June 30 1925, 10.

${ }^{90}$ These debates are well-rehearsed in studies of the era. For detailed analyses that make particular references to Hyde's role, see Chris Hilliard, The Bookmen's Dominion: Cultural Life in New Zealand 1920-1950 (Auckland: Auckland University Press, 2006), 97-99; and Lawrence Jones, Picking up the Traces: The Making of a New Zealand Literary Culture 1932-1945 (Wellington: Victoria University Press, 2003), 82-103.

${ }^{91}$ Jones, Picking up the Traces, 86.

${ }^{92}$ Stuart Murray, Never a Soul at Home: New Zealand Literary Nationalism and the 1930s (Wellington: Victoria University Press, 1998), 10.

${ }^{93}$ Denis Glover, "The Arraignment of Paris." in Denis Glover: Selected Poems, ed. Bill Manhire (Wellington: Victoria University Press, 1996), 91-98. 